\title{
Survival and acclimatation of Populus nigra to drier conditions after damming of an alpine river, southeast France
}

\author{
Luc LAMBS $^{\mathrm{a} *}$, Mathieu LOUBIAT ${ }^{\mathrm{a}}$, Jacky GIREL ${ }^{\mathrm{b}}$, Jérôme TISSIER $^{\mathrm{b}}$, Jean-Paul PELTIER $^{\mathrm{b}}$, Gérard MARIGO $^{\mathrm{b}}$ \\ ${ }^{a}$ Laboratoire Dynamique et Biodiversité-CNRS, FR Écologie, 29 rue Marvig, 31055 Toulouse Cedex 05, France \\ ${ }^{\mathrm{b}}$ Laboratoire d'Écologie Alpine, UMR 5553, Université Joseph Fourier, BP 53, 38041 Grenoble Cedex 9, France
}

(Received 23 June 2005; accepted 12 October 2005)

\begin{abstract}
Poplars occur in riparian areas where the water table depth generally varies with the elevation of the adjacent river. Changes in stream flow caused by diversion projects can affect the riparian community; this may lower the water table below the rooting zone of some tree species and cause then to suffer from a water shortage. Obligate riparian trees require access to a permanent water supply and are usually intolerant to low water potentials, being poorly adapted to water stress. In this paper, the survival of black poplars (Populus nigra) downstream of a dam constructed in the 1960s on the Drac river at the foot of the French Alps is reported. The growth, water consumption, and water status of some of these trees are compared with those of other poplars located downstream and growing under wetter conditions. Although water consumption and development were quite different for both, their method of water regulation seemed to be quite similar.
\end{abstract}

Populus nigra / dendrochronological studies / sap flow / drought tolerance

Résumé - Survie et adaptation de Populus nigra à des conditions plus sèches suite à la construction d'un barrage sur une rivière des Alpes dans le sud-est de la France. Les peupliers poussent le long des rivières où la profondeur de la nappe varie avec le niveau de la rivière adjacente. Les changements de débit suite aux modifications de l'écoulement, peuvent affecter les forêts riveraines : ceci peut faire abaisser la hauteur de la nappe en dessous du système racinaire de certains arbres et leur réduire ainsi l'accès à l'eau. Ces arbres phréatophytes ont besoin d'un accès permanent à l'eau et sont généralement intolérant à la sécheresse et peut adaptés au stress hydrique. Dans cette étude, la survie de peupliers noirs (Populus nigra) en aval d'un barrage construit dans les années 1960 sur le Drac au pied des Alpes est décrite. La croissance, la consommation en eau et l'état hydrique de ces arbres sont comparés à d'autres peupliers poussant plus en aval dans des zones plus humides. Bien que leur consommation en eau et leur développement sont différents, leur mode de régulation de l'eau semble bien être similaire.

Populus nigra / dendrochronologie / flux de sève / tolérance à la sécheresse

\section{INTRODUCTION}

Poplars are species adapted to physically dynamic riparian zones such as river valley floodplains. These trees are ecological pioneers, with prolific seed production, rapid germination and vigorous growth [26]. However, with the restriction of wet areas caused by river management or by stream diversions, which lead to deeper ground water levels, many riparian trees are now growing in drier conditions. Reduced water availability associated with low flows may affect the water relations of obligate riparian species and reduce growth, performance and survival. Prolonged periods of poor growth and low survival will inevitably lead to altered population structures and potential successional shifts in community composition [30]. In North America, three-quarters of the forest poplars of the western prairies and mountain foothills have been estimated as lost, mainly due to damming [34].

When poplar trees are exposed to drought, they close their stomata, shed leaves and increase root growth to postpone dehydration. A moderate decline in water potential may close

\footnotetext{
*Corresponding author: lambs@cict.fr
}

stomata, but more severe moisture stress causes photosynthesis to cease [12]. Under drought conditions, phloem transport continues until photosynthesis reaches quite low levels [6], which tends to shift carbon allocation away from new leaves and branches and towards root initiation. Finally, the water potential in the plant forms a gradient from least negative in the roots to most negative towards the uppermost shoots. Therefore, drought-induced water stress commences at the crown and progresses inwards towards the trunk and finally to the roots.

Poplar leaves usually display very large stomatal conductances that lead to high transpiration rates. Poplar transpiration, however, is poorly coupled to the atmosphere [10], and even under conditions of intense solar radiation, warm temperatures and brisk wind, the unique characteristics of poplar canopies moderate the amount of water actually lost through transpiration [5]. In dry years, but not in high runoff years, riparian plants on diverted reaches have reduced stomatal conductance and water potentials compared to plants on undiverted reaches. For long-term acclimation, plants on diverted reaches possessed significantly smaller, thicker leaves 
and a reduced total leaf area relative to trees on streamside reaches [30].

In the present study, the growth rate and water consumption of a group of polycormic poplars in a dry area were determined. For two of these trees, sap flow and climatic factors were monitored over the dry season. To understand the acclimation of these poplars to drought, physiological parameters on the leaves and twigs were also measured. Poplars growing at two other sites under wetter conditions were studied as well: one also along the Drac river, but more downstream, and one along the Isère river. The study was conducted to compare water regulation between the trees.

\section{MATERIALS AND METHODS}

\subsection{Site description}

\subsubsection{Drac site}

The dryer site is located between St Georges de Commiers and Grenoble ( $45^{\circ} 04^{\prime} \mathrm{N}, 5^{\circ} 43^{\prime}$ E, elevation $280 \mathrm{~m}$ ) near the Drac river, which has been partly dried up by a dam construction in 1959 . On this gravel and sand plain (maximum depth is $1.5 \mathrm{~m}$ ), medium-sized poplars (6-8 $\mathrm{m}$ high) with dry branches in the crown and numerous yellow leaves, are found in association with Fraxinus excelsior, Acer opalus, and a few Pinus sylvestris. All poplars had a polycormic form or big low branches, thick bark, and small leaves. No young trees could be seen. On a quadrat of about $15 \times 15 \mathrm{~m}$, four poplars with multiple stems of similar girth, 70-80 cm, were studied and noted: P1 (three stems), P2 (seven stems), P3 (four stems), and P4 (three stems).

\subsubsection{Rochefort site}

Wetter than the Drac site, the Rochefort site is located between the Grand Rochefort Hill and the Drac river [22], just upstream from Le Pont de Claix ( $45^{\circ} 07^{\prime} \mathrm{N}, 5^{\circ} 42^{\prime}$ E, elevation $248 \mathrm{~m}$ ). At this location, the Drac river has two tributaries, the Romanche and Gresse rivers. On this gravel and silt soil (maximum depth is $1.5 \mathrm{~m}$ ), black poplars (main species) of different ages are growing with Alnus incarna and Salix alba. On a quadrat of about the same size, three poplars were also studied: P5 (girth $76 \mathrm{~cm})$, P6 $(98 \mathrm{~cm}$ ), and closer to the river, P7, the largest tree $(192 \mathrm{~cm})$.

\subsubsection{Campus site}

The third and wettest site is located along the Isère river, about $10 \mathrm{~km} \mathrm{NE}$ of the Rochefort site, on the campus of the University of Grenoble $\left(45^{\circ} 20^{\prime} \mathrm{N}, 5^{\circ} 30^{\prime} \mathrm{E}\right.$, elevation $\left.200 \mathrm{~m}\right)$. The poplars are growing in a mixed stand with $F$. excelsior, Acer pseudoplatanus and Tilia cordata on a deep alluvial soil (fine sand and silt over $5 \mathrm{~m}$ thick). The studied poplar, P8, is a large tree (girth $480 \mathrm{~cm}$, height $25 \mathrm{~m}$ ) with a main trunk of $2 \mathrm{~m}$ in height divided into three wide branches (girth 180-234 cm). Two other trees of similar size were also used at the two sites to determine water relations and hydraulic characteristics.

\subsection{Dendrochronological studies}

In May 2002, before the installation of the sap flow sensors, wood cores (diameter $5 \mathrm{~mm}$ ) were extracted with an increment borer for the estimation of the sapwood width on poplars P1 (Drac) and P8 (Campus). After cores were stuck to a wooden support and sanded with fine paper, ring widths were measured and the sapwood depth was estimated by the change of colour.

In April 2005, the global dendrochronological study was undertaken. Wood cores were taken from numerous poplars stems at the Drac site. Some stems were also cut to obtain disks with which to check core information; it was not always easy to read poplar wood because of the twisted nature of the cores. For the disks, measurements of tree ring width were performed along two perpendicular axes. All details are given in Table I. Two conifers growing at this site were also cored (one pine and one juniper). Additional poplars were sampled at the Rochefort site: wood cores for P5 (a tree with a diameter similar to that at the Drac site) and P7, and a disk for P6.

\subsection{Sap flux measurements}

In order to determine variations and the water requirements of trees at the dry Drac site during summer, two poplar stems from the P1 group were equipped with Granier-type [7] sap flux sensors $(2 \mathrm{~cm}$ long). The sensors were installed at a height of about $0.5 \mathrm{~m}$ on the north side of P1-1 and P1-2 (diameters of 26 and $24 \mathrm{~cm}$ ), the stems themselves facing south. The bark was abnormally hard for a poplar and could not be removed with the wooden chisel without the help of a hammer. The measurements were performed from 14 May 2002 to 30 July 2002, with 65 days of effective values (missing days: 417 June).

To understand the water needs and regulation of poplars under wetter conditions at the Campus site, poplar P8 (diameter $153 \mathrm{~cm}$ ) was also equipped with sap flow sensors. The sensors were installed on the north side of the two main branches (diameters of 75 and $73 \mathrm{~cm}$ ), the branches relative to the tree facing south, at a height of about $3 \mathrm{~m}$. The measurements were performed from 13 May 2002 to 8 August 2002, with 73 days of effective values (missing days: 31 May to 8 June and 11-16 June).

The data logger recorded the sap flux values (mean value of the measurements made every $30 \mathrm{~s}$ ) as well as the air temperature and air humidity every $10 \mathrm{~min}$. The results are given as sap flux densities (SFD), as obtained using the Granier [7-9] calibration formula:

$$
\operatorname{SFD}(u)=4.28 \times[\Delta T(0) / \Delta T(u)-1]^{1.231} \text { in } \mathrm{dm}^{3} \mathrm{dm}^{-2} \mathrm{~h}^{-1}
$$

where $\Delta T(0)$ represents the temperature difference between the two probes at night when the sap flow ceases and $\Delta T(u)$ is the temperature difference at the given time $u$.

\subsection{Water potential, stomatal conductance and hydraulic conductivity}

Leaf water potential $(\Psi)$, stomatal conductance $(G s)$ and transpiration $(E)$ were monitored during the wet (June) and dry (July) seasons at both sites P1 and P8. Leaf water potential was assessed with a Scholander pressure chamber, and predawn leaf water potentials $\left(\Psi_{\mathrm{wp}}\right)$ were measured before sunrise. Stomatal conductance 
Table I. Location and characteristics (number of stems, diameter of main trunk, beam of the sub-stem or main branch, and thickness of the sapwood) of the studied poplars at the three sites. The type of wood extraction is also given (wood core or disk), as well as if other measurements were made. SF: sap flux.

\begin{tabular}{|c|c|c|c|c|c|c|c|c|c|}
\hline Location & Name & Nber of trunk & $\begin{array}{l}\text { Main diam } \\
\quad(\mathrm{cm})\end{array}$ & Sub-stem & $\begin{array}{c}\text { Beam } \\
(\mathrm{cm})\end{array}$ & $\begin{array}{l}\text { SW wide } \\
\text { (cm) }\end{array}$ & Disk & Core & Other \\
\hline \multirow[t]{7}{*}{ Drac } & $\mathrm{P} 1$ & 3 & 66 & $\mathrm{P} 1-1$ & 13.1 & 1.9 & & $x$ & $\mathrm{SF}$ \\
\hline & & & & P1-2 & 11.7 & 1.8 & & $x$ & SF \\
\hline & & & & P1-3 & 10.1 & 1.6 & $\times$ & & \\
\hline & $\mathrm{P} 2$ & 7 & & $\mathrm{P} 2-1$ & 11.6 & 1.5 & & $x$ & \\
\hline & & & & $\mathrm{P} 2-2$ & 9.9 & 1.3 & $x$ & & \\
\hline & P3 & 4 & & P3-1 & 12.6 & 1.6 & & $x$ & \\
\hline & P4 & 3 & & P4-1 & 12.5 & 2.1 & & $x$ & \\
\hline \multirow[t]{3}{*}{ Rochefort } & P5 & 1 & 24 & & 12 & 1.9 & & $x$ & \\
\hline & P6 & 1 & 31 & & 15.5 & 3.7 & $x$ & & \\
\hline & P7 & 1 & 61 & & 30.5 & $>5.6$ & & $x$ & \\
\hline \multirow[t]{2}{*}{ Campus } & P8 & 1 & 153 & P8-1 & 37.3 & 6.7 & & $x$ & $\mathrm{SF}$ \\
\hline & & & & P8-2 & 36.6 & 6.5 & & $x$ & $\mathrm{SF}$ \\
\hline
\end{tabular}

and transpiration were measured hourly with a Li-Cor-1600 porometer (Li-Cor, Lincoln, NE, USA). Xylem water potentials ( $\left.\Psi_{\text {xylem }}\right)$ were estimated by measuring the water potential of leaves that had been enclosed in aluminium foil and a plastic bag early in the morning $[3,32]$. Hydraulic conductivity was measured on twigs obtained from branches collected in the morning from mature trees using the procedure described by Lemoine et al. [14]. The branches were enclosed in black airtight plastic bags to reduce water loss through transpiration and quickly brought to the laboratory for hydraulic analysis. In the laboratory, the branches were cut again under water. After rehydration, segments about $2-3 \mathrm{~cm}$ long were excised under water from different branches, shaved at both ends with a razor blade and then fitted to plastic tubes at the basal end. The segments were then perfused with deionized water at a pressure difference of $0.1 \mathrm{MPa}$ to eliminate any air embolisms and to restore the full capacity of the xylem. Maximum conductivity was determined by forcing distilled water with a pressure difference of $3.7 \mathrm{kPa}$ through each sample. The resulting flow rate $\left(\mathrm{mmol} \mathrm{s}^{-1}\right)$ was measured using an analytical balance. The specific conductivity was calculated as the ratio between the maximum conductivity and the mean cross-sectional area of the twig sample (without bark). Vulnerability curves (VCs) were established for excised well-watered branches in which embolism was induced in a long pressure chamber $(0.4 \mathrm{~m})$ using the method described by Cochard et al. [2]. The air pressure in the chamber was maintained at the designated values (between 1 and $5 \mathrm{MPa}$ ) using nitrogen until sap exclusion ceased (after 10-60 min, depending on the pressure applied). For each pressure application, the percent loss of hydraulic conductivity (PLC) was measured for six to eight randomly selected segments. $\Psi_{\text {cav }}, \Psi_{50 \%}$, and $\Psi_{100 \%}$, which indicate the water potential values that induced the start of the embolism and $50 \%$ and $100 \%$ of the maximal hydraulic conductivity, respectively, were measured graphically from each VC. Duplicate VCs were produced for two trees at each studied site. For the two trees, determinations of the hydraulic characteristics were made on July 2002.

\subsection{Statistical analysis}

Analysis of variance (ANOVA) was used to compare the specific conductivity of the two trees at each studied site. The analyses were performed with SPSS 9.0 (SPSS Inc, Chicago, IL, USA).

\section{RESULTS}

\subsection{Dendroecological studies}

The main results are presented in Table I and in Figure 1A (dry area) and Figure 1B (wet area). From the dry area along the Drac river, its can be clearly seen that all trees (P1-P4, see Fig. 1A) displayed little growth with a mean value of $0.8 \mathrm{~mm}$ year $^{-1}$ during the first 45 years (from 1960-2004). Following this, growth increased progressively to $4-6 \mathrm{~mm} \mathrm{year}^{-1}$. The sapwood of these poplars was quite narrow $(1.3-2.1 \mathrm{~cm})$, which is very unusual for poplars. However, it totalled many tens of tree rings.

It is interesting to note that the dendrochronological curve of the pine, $P$. sylvestris, which has a girth of $183 \mathrm{~cm}$ and is growing in the middle of these poplars, also displays the same profile (data not shown): low growth, about $3 \mathrm{~mm}_{\text {year }}{ }^{-1}$ during the first 45 years, and then increases to $5-8 \mathrm{~mm}_{\text {year }}{ }^{-1}$. For an older juniper (Juniperius communis) with a girth of $31 \mathrm{~cm}$ growing in the same area, although an analysis shows more regular growth, the difference between the two periods is still visible: mean growth of $0.65 \mathrm{~mm}_{\text {year }}{ }^{-1}$ for the first 45 years, and then the growth increases to $0.80 \mathrm{~mm}_{\text {year }}{ }^{-1}$ for the next 55 years.

At the second wettest area, the Campus site near the Isère river, the wood cores of poplar P8 display wide tree rings 
A.1
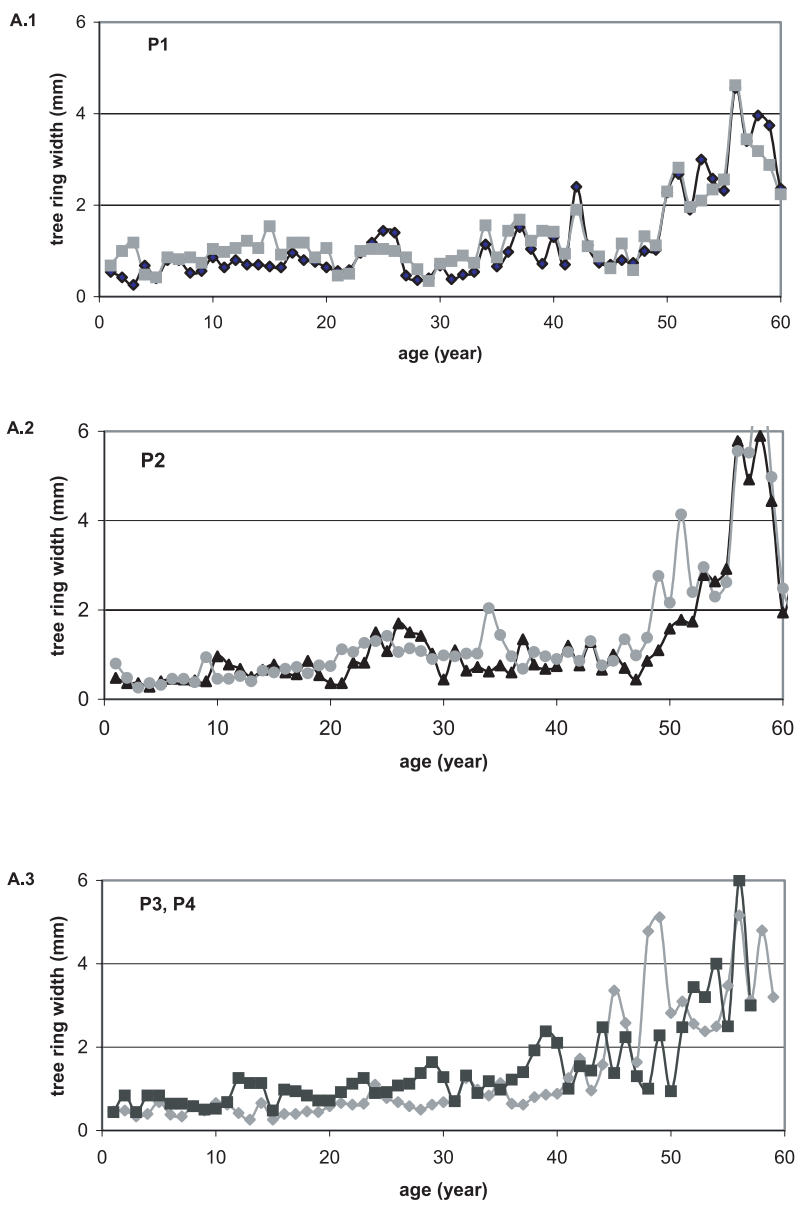

B.1

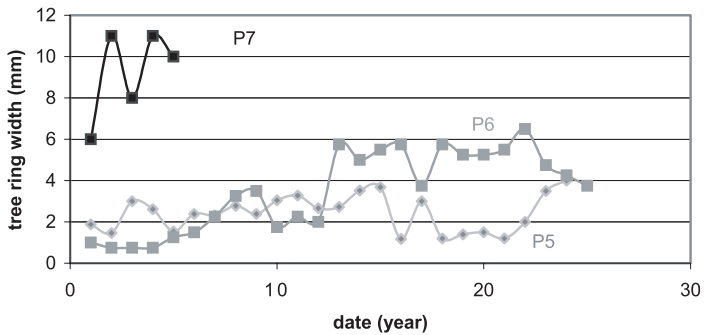

B.2

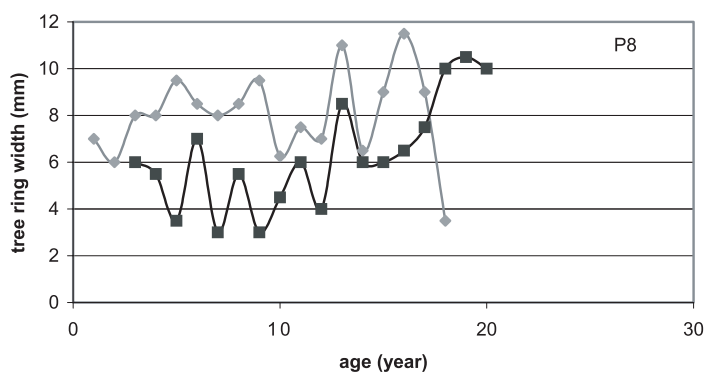

Figure 1. A. Comparison of the annual growth of poplars P1 (A.1 panel), P2 (A.2 panel) and P3, P4 (A.3 panel) from the dry Drac site as obtained from wood cores and disks. The abscised axis is expressed as the age of the tree rings (i.e., 1 for 2004, 44 for 1960, following river diversion by the dam). B. Comparison of the annual growth of poplars at the Rochefort site (poplars P5-P7, panel B.1) and the Campus site (poplar P8, panel B.2). 

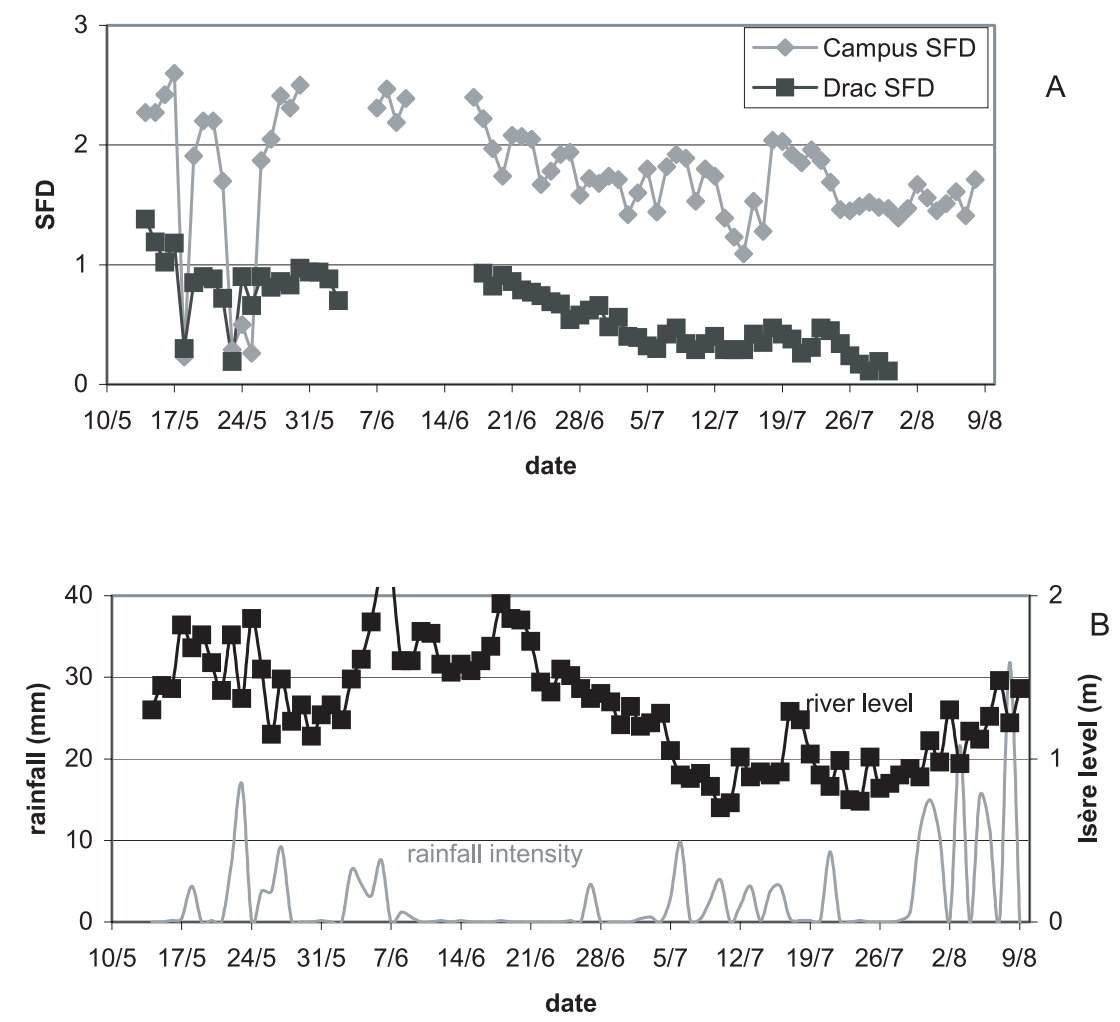

Figure 2. A. Evolution of the daily maximum sap flux density (SFD) of both poplars over the 2002 season: dry Drac poplar (P1, grey lozenge) and wet Campus poplar (P8, dark square) and as calculated from the thermocouple data. B. Hydrological parameter (Isère river level) and meteorological parameters (rainfall from the Versoud station) during the sap flow measurements.

(mean value around $6 \mathrm{~mm}$, see Fig. 1B, panel down). The chronology is shorter due to limitations of the increment borer length. Sapwood is also wider (about $6.6 \mathrm{~cm}$ ) and corresponds to $6-10$ tree rings.

For the intermediate site, Rochefort, the three obtained profiles on Figure 1B, panel up, show variable growth: 1-4 mm for P5, 1-6 mm for P6, and 6-11 mm for P7, which was located closer to the river. For this last tree, the wood core was blocked in the increment borer because of the presence of wetwood. Overall, these values ranged between the limits found at the others sites. The sapwood width here (see Tab. I) also seems to be linked with hydrological conditions: narrow sapwood $(1.9 \mathrm{~cm})$ for P5 such as at the dry Drac site, wider sapwood $(>5.6 \mathrm{~cm})$ for P8 such as at the wetter Campus site, and intermediate values $(3.7 \mathrm{~cm})$ for $\mathrm{P} 6$, which displays a more variable growth rate.

An attempt to quantify the vessel diameter revealed smaller vessels in the Drac tree sapwood (P1) compared to the campus tree sapwood (P8). However, due to technical limitations, the effective vessel density could not be numbered exactly.

\subsection{Comparison of sap flux densities of poplar trees growing in poorly watered and well-watered plains}

Figure 2A reports the comparison of sap flux densities of the Drac (P1) and Campus (P8) trees over the summer of 2002.
To give better clarity, only one pair of sensor results per tree is provided. Over the period of the entire experiment, the Drac site values were about two times lower than those at the campus site: about $2 \mathrm{dm}^{3} \mathrm{dm}^{-2} \mathrm{~h}^{-1}$ for the campus poplar and $1 \mathrm{dm}^{3} \mathrm{dm}^{-2} \mathrm{~h}^{-1}$ or less for the Drac poplar. The first three drops, on 18, 23 and 25 May, were due to rainy and cloudy days. After mid-June at both sites, lower sap flux densities were measured.

Figure 2B summarizes the hydrological parameters for the sampled period. The total rainfall in May 2002 was $152 \mathrm{~mm}$, dropped to $29 \mathrm{~mm}$ in June, increased to $74.8 \mathrm{~mm}$ in July and increased again to $140 \mathrm{~mm}$ in August. There was a very dry period from 7 June to 26 June, when only $2.6 \mathrm{~mm}$ of rain fell in 20 days. Although there were no piezometers to quantify measurements, the Isère river level provided an idea of the groundwater variation, because both parameters are linked. Indeed, following a slight delay, the river level dropped with the reduced rainfall between mid-June to mid-July, which was well correlated with a decline in sap flow.

\subsection{Analysis of tissue water relations}

The high value of the predawn leaf water potential $\left(\Psi_{\mathrm{wp}}\right)$ observed (close to 0 ) indicates that the soil water supply for both trees in their respective habitats was sufficient in June (Tab. II). Despite the apparently well-watered soil, the 
Table II. Some plant water relationships in leaves of $P$. nigra trees growing in poorly watered (P1 and P2, Drac river) and well-watered (P8 and adjacent poplar, Campus) floodplains. Data are the mean of 10 determinations $\left( \pm\right.$ SD) from two trees. $\Psi_{\mathrm{wp}}$ is the predawn leaf water potential and $\Psi_{\mathrm{m}}$ is the minimum midday leaf water potential. $G s_{\max }$ and $E_{\max }$ are the maximum values for stomatal conductance and transpiration, respectively. Identical experiments conducted the previous year (2001) led to the same data.

\begin{tabular}{|c|c|c|c|c|c|}
\hline \multirow[t]{2}{*}{ Date } & \multirow[t]{2}{*}{ Site } & $\Psi_{\mathrm{wp}}$ & $\Psi_{\mathrm{m}}$ & $G s_{\max }$ & $E_{\max }$ \\
\hline & & \multicolumn{2}{|c|}{$\mathrm{MPa}$} & \multicolumn{2}{|c|}{$\mathrm{mmol} \mathrm{m}{ }^{-2} \mathrm{~s}^{-1}$} \\
\hline \multirow[t]{2}{*}{$06 / 02 / 2002$} & Drac & $-0.20 \pm 0.00$ & $-1.70 \pm 0.15(7 \mathrm{~h})$ & $100 \pm 11(7 \mathrm{~h})$ & $2.15 \pm 0.15$ \\
\hline & Campus & $-0.15 \pm 0.05$ & $-1.60 \pm 0.10(9 \mathrm{~h})$ & $270 \pm 19(9 \mathrm{~h})$ & $4.25 \pm 0.30$ \\
\hline \multirow[t]{2}{*}{$07 / 02 / 2002$} & Drac & $-1.1 \pm 0.10$ & $-1.75 \pm 0.15(7 \mathrm{~h})$ & $40 \pm 7(7 h)$ & $0.75 \pm 0.10$ \\
\hline & Campus & $-0.10 \pm 0.00$ & $-1.65 \pm 0.10(9 h)$ & $285 \pm 21(9 h)$ & $4.50 \pm 0.31$ \\
\hline
\end{tabular}

stomatal conductance and transpiration of the Drac poplar were about two times lower than that of the campus tree. These low values for the transpiration rate may be related to the sap flux density of the Drac tree, which also decreased by a factor of two in comparison to the campus tree. The first sign of water depletion of the Drac station appeared in July, with a noticeable $\Psi_{\text {wp }}$ decrease of the local poplar (to about $-1.1 \mathrm{MPa}$ ). A strict control of water status seems to occur in the two trees via stomatal regulation. In such environmental water conditions, $\Psi_{\mathrm{m}}$ did not decrease under a mean value of $-1.65 \mathrm{MPa}$. When this value was reached, the stomatal conductance and transpiration then began to decrease, indicating that the stomata had closed. This event occurred earlier for the Drac poplar (at 7 am for $\Psi_{\mathrm{m}}$ and $G s_{\max }$ ), with a delay of two hours for the campus tree ( $\Psi_{\mathrm{m}}$ and $G s_{\max }$ at $\left.9 \mathrm{am}\right)$.

\subsection{Hydraulic characteristics and vulnerability to embolism}

Previous measurements made on the Drac and Campus site trees in 2001 showed that the specific hydraulic conductivities of poplar branches, respectively $46.4 \pm 2.7(n=41)$ and $41.3 \pm 2.5(n=32) \mathrm{mol} \mathrm{s}^{-1} \mathrm{MPa}^{-1} \mathrm{~m}^{-1}(n$, number of replicates from two individual trees), were not statistically different (ANOVA, $p>0.05$ ) between the two trees studied. Both trees were also very sensitive to drought conditions, and twigs obtained from 1-year-old branches showed similar vulnerability to cavitation processes, with the following critical points for the xylem water potential: $\Psi_{\text {cav }},-0.5 \mathrm{MPa} ; \Psi_{50 \%},-0.75 \mathrm{MPa}$; $\Psi_{100 \%},-1.25 \mathrm{MPa}$ (Fig. 3).

\section{DISCUSSION}

The importance of water to a plant lies in its role in cell expansion, cooling of leaves, nutrient and carbon transport and photosynthesis. Poplars are thought to consume large amounts of water to support their rapid growth rates and display a short lifespan. However, a close analysis of their water use disputes this view [5]. Other papers report the acclimatation and plasticity of poplar trees such as the existence of a riparian woodland of very old cottonwood, with ages of up to 400 years [27],

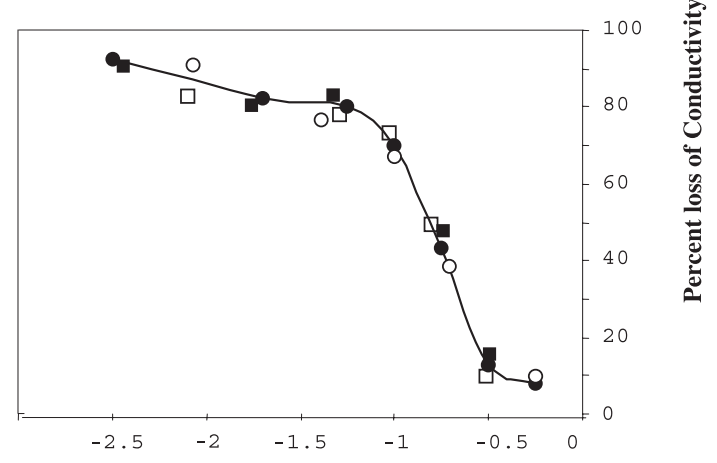

Pressure MPa

Figure 3. Comparison of the vulnerability to embolism for poplars in two contrasting areas. The measurements were conducted on two trees growing in the dry site (P1 and P2, empty symbols) and two trees that originated from the wet site (P8 and adjacent poplar, full symbols). Each value on the graph is a mean of six to eight replicates. The standard errors, which did not exceed 5\% of the mean values, are not reported.

or the very low growth of trembling aspen in boreal conditions, as low as $1.2 \mathrm{~mm}$ year $^{-1}$ [11].

In our previous study on water consumption of black poplars along the Garonne River, we found SFD values ranging from $1.5-2.6 \mathrm{dm}^{3} \mathrm{dm}^{-2} \mathrm{~h}^{-1}$, with mean values around $2 \mathrm{dm}^{3} \mathrm{dm}^{-2} \mathrm{~h}^{-1}$ [13]. Similar value or little higher values were reported by different authors $[21,28,37]$. Sap flow measurements on hybrid poplars have also been taken in Belgium [10,18] and Canada [11], but the different kind of sap sensors used (Cermak type or heat pulse) avoids any possible comparison. During the drought of 1998, the SFD values of the Garonne poplar dropped to $1 \mathrm{dm}^{3} \mathrm{dm}^{-2} \mathrm{~h}^{-1}$, and even as low as 0.3 for a few days, which was followed by a loss of leaves. The Drac poplar was seen to be in this water stress situation during the whole growing season.

It is more difficult to obtain figures for the water consumption of the whole tree because the sapwood of poplars can be quite thick [19]. Some authors have even given the relationship between the sapwood area (SWA) and the diameter at breast 
height $(\mathrm{DBH})(\mathrm{cm})$ as: $\mathrm{SWA}=6.39 \times \mathrm{DBH}^{1.25}[28,35]$. However, for the narrow sapwood of the Drac poplar here, this is not applicable. In this case, as for some hardwood trees such as oak, the $2 \mathrm{~cm}$ long sensor is close enough to the sapwood width to directly calculate the water used. For the $22 \mathrm{~cm}$ wide stem, this gives a water consumption of about $20 \mathrm{ld}^{-1}$ for the high SFD value in May-June, and only $41 \mathrm{~d}^{-1}$ during the lower SFD value in July-August.

From our previous study along the Garonne river on 30 black sampled poplars (unpublished data), a mean growth of $6.54 \pm 2.05 \mathrm{~mm} \mathrm{year}^{-1}$ was found. The value found here for the poplar at the Campus site is very similar $6.39 \mathrm{~mm} \mathrm{year}^{-1}$. However, for some trees located further from the Garonne river and during dry years, growth was reduced to $1 \mathrm{~mm}$ year $^{-1}$. These exceptionally low growth values seem to have been normal for the Drac poplar since the river was diverted in the 1960s. Although it appears that even under these drastic conditions, the few remaining poplars were able to survive for more than 40 years, new poplars trees were unable to settle. What is also interesting is that all of the observed trees present a similar diameter and that the cores show that they are all about the same age (60-70 years). These few examples show the growth range of the black poplar and their acclimatation to soil moisture.

Fine sanding of the wood cores has also revealed the distribution and dimensions of vessels. The apparent diameter of $50-100 \mu \mathrm{m}$ is in good agreement with the values of $40-95 \mu \mathrm{m}$ found in the literature [25]. This reference also gives the average number of vessels as $25-70 \mathrm{~mm}^{2}$, which could not be counted in our samples. The fact that the sapwood from the Drac area displays smaller vessels in comparison with the numerous wider vessels from the campus area could postulate for a higher sap hindrance during the water uptake of the former area, followed by a lower sap flux density.

Water potentials and other water-relation parameters usually correlate poorly with growth in the field where water stress limits growth on a daily basis. There are a number of reasons why it is difficult to correlate growth in the field, which is cumulative, with physiological parameters, which are measured instantaneously. As a result, physiological adjustments of the plant to chronic water stress are complex and poorly documented [5]. In the poplar, our studies show that the major consequence of dry soil conditions, whether combined with a high water demand resulting from climatic conditions or not, is the limitation of stomatal conductance. The control of stomata is advantageous because it allows early limitation of water loss. Stomatal responses to water stress are related to leaf water potentials [29], and stomata begin to close after certain leaf water potential levels have been reached [36]. For poplar trees, the leaf water potential may drop to relatively low values before the stomata begin to close (around $-1.75 \mathrm{MPa}$ ), but when this critical value is reached the water potential does not continue to decrease during the day or with increased drought conditions due to the rapid closure of stomata. Stomatal regulation, therefore, seems to be very efficient in the poplar for controlling water status.

Indeed, the limited transpiration measured on the Drac tree could be related to a smaller sap flux density. However, the same result could be obtained with a smaller sapwood area and similar SFDs. Effectively, if we compare the values of the two trees at the beginning of June, the sap flux density of the Drac poplar was two times lower than for the poplar from the campus area (see Fig. 2A, respectively about 1.0 and $2.4 \mathrm{dm}^{3} \mathrm{dm}^{-2} \mathrm{~h}^{-1}$ ). From the transpiration results, we also obtained the same ratio (respectively $E_{\max }$ equal to 2.15 and $4.25 \mathrm{mmol} \mathrm{m}^{-2} \mathrm{~s}^{-1}$ ). In July, although the difference was enhanced between the two trees, the ratio, now about 5$6 \mathrm{~mm}^{2} \mathrm{~s}^{-1}$, was similar for both trees.

With regard to sapwood widths, the Drac poplar sapwood was three to four times thinner than the campus poplar (respectively 1.8 and $6.5 \mathrm{~cm}$ ). This $1.8 \mathrm{~cm}$ for the Drac poplar represents about 30 active tree rings, whereas the $6.5 \mathrm{~cm}$ of the campus poplar corresponds to only 10 active tree rings. The ratio, as seen from the number of active tree rings, is reversed. It is as if the Drac poplar compensates in part for a lower yield of its tree rings (due to the smaller vessels) with a higher number of active tree rings. The SFD values, as calculated per unit of sapwood area from a transverse section, are independent of the global sapwood area. As they are for leaf levels, transpiration measurements are integrative for the active part of the sapwood. The other physiological measurements show that both trees have the same method of stomatal regulation. However, in our case, there are two limiting factors for the Drac poplar: a lower SFD and a smaller sapwood area.

Water movement in trees can be now track by IR detector [20]. There is now ample evidence to indicate that the hydraulic architecture of trees may be related to the processes of drought adaptation $[1,4,33,38]$. For poplar trees, the hydraulic characteristics of branches seem to be very species-specific and not related to the climatic conditions of the studied site. Indeed, when comparing the two poplars at their respective sites, there is no modification in hydraulic conductivity or vulnerability to drought cavitation. This hydraulic behaviour can be related to that of $F$. excelsior, a species that frequently occurs with poplar trees. Ash trees have a broad ecological amplitude [16, 17, 23, 24], the same for maple trees [31], particularly because they can acclimatize to limited water availability by increasing their resistance to cavitation [14]. As demonstrated in this study, poplar species did not have this adaptation potential of hydraulic architecture. Therefore, their survival in dry conditions should be related to other mechanisms. During drought periods, a regular loss of leaves and branches occurs because of cavitation, i.e., the vessels in the wood fill with air and embolize. Cavitation commences first in the lower crown, which is another reason why lower leaves firstly yellow and abscise under drought, then progresses to the upper stem, while the growing apex is the last to cavitate. This mechanism preserves the dominance of the main stem over the lateral branches under drought and ensures the survival of the growing apex [5].

Why do poplar trees cavitate so easily? Among the temperate zone species tested, poplars have the highest vulnerability to drought induced xylem dysfunction. Populus balsamifera and P. angustifolia display a 50\% loss of conductivity at about $-1.5 \mathrm{MPa}$, whereas $P$. deltoides, which is more closely related to P. nigra, displays a $50 \%$ loss of conductivity at 
$-0.5 \mathrm{MPa}$ [34]. In Grenoble, no difference was seen between the two black poplars, which had similar values of around $-0.55 \mathrm{MPa}$ for their cavitation potentials. If we compare this value to that of the xylem water potential reached at midday, -0.55 to $-0.60 \mathrm{MPa}$ (mean value of 10 determinations from two trees at the wet site, data not shown), it can be concluded that, as with other species [15], poplar trees are close to the limit of xylem dysfunction, even when soil water availability is not limited. Under dry conditions, a 50\% loss of hydraulic conductivity should occur for a xylem potential decrease of $-0.75 \mathrm{MPa}$, and complete embolism should occur from $-1.25 \mathrm{MPa}$.

\section{CONCLUSION}

While poplars in wet areas are known for their rapid growth and high sap flux densities, they can also adapt to some extent to drier zones with lower growth and unusually low sap flow values over many weeks. The poplars along the Drac river could survive over 40 years in these extreme conditions, perhaps because the ground water decline is very progressive and because the drought season at the foot of the Alps is not too long. They display similar water regulation patterns to poplars growing in wetter conditions. That is, they have the same stomatal closure, the same hydraulic properties, and have a high vulnerability to cavitation. The only difference is that the poplar in the driest area limited the cavitation effects to the crown branches by hydraulic segmentation. Their thicker bark and smaller leaves should also reduce water loss. The fact that these trees have lower growth and narrower sapwood, coupled with their lower sap flux densities (perhaps due to their smaller vessels), means they can survive with a smaller quantity of water.

Acknowledgements: We are grateful to E. Muller, Ladybio Toulouse, for the programming of the data logger, to T. Gauquelin for access to the dendrometric equipment, and C. Pelissier for sanding and tree ring counting. Valuable critical comments were provided by the anonymous reviewers. The European Commission funded this study, contract EVK1-1999-000154 (Flobar 2 programme).

\section{REFERENCES}

[1] Cochard H., Tyree M.T., Xylem dysfunction in Quercus: vessel sizes, tyloses, cavitation and seasonal changes in embolism, Tree Physiol 6 (1990) 393-407.

[2] Cochard H., Bréda N., Granier A., Aussenac G., Vulnerability to air embolism of three European oak species (Quercus petraea (Matt) Liebl., Q. pubescens Will., $Q$. robur L.). Ann. Sci. For. 49 (1992) 225-253.

[3] Cochard H., Lemoine D., Dreyer E., The effects of acclimation to sunlight on the xylem vulnerability to embolism in Fagus sylvatica L., Plant Cell Environ. 22 (1999) 101-108.

[4] Cruiziat P., Cochard H., Améglio T., Hydraulic architecture of trees: main concepts and results, Ann. For. Sci. 59 (2002) 723-752.
[5] Dickman D.I., Isebrands J.G., Blake T.J., Kosola K., Kort J., Physiological ecology of poplars, in: Dickman D.I., Isebrands J.G., Eckenwalder J.E., Richardson J. (Eds.), Poplar Culture in North America, Part A, Chapter 3, NRC Research Press, National Research Council of Canada, Ottawa, ON K1AOR6, Canada, 2001, pp. 77-108.

[6] Ericsson T., Rytter L., Vaavuori E., Physiology of carbon allocation in trees, Biomasss Bioenergy 11 (1996) 317-345.

[7] Granier A., A new method to measure the raw sap flux in the trunk of trees, Ann. Sci. For. 42 (1985) 193-200.

[8] Granier A., Biron P., Breda N., Pontallier J.-Y., Saugier B., Transpiration of trees and forest stands: short and long-term monitoring using sapflow methods, Global Change Biol 2 (1996) 265274.

[9] Granier A., Biron P., Lemoine D., Water balance, transpiration and canopy conductance in two beech stands, Agr. For. Meteorol. 100 (2000) 291-308.

[10] Hinckley T.M., Brooks J.R., Cermak J., Ceulemans R., Kucera J., Meinzer F.C., Roberts D.A., Water flux in a hybrid poplar stand, Tree Physiol. 14 (1994) 1005-1018.

[11] Hogg E.H., Hurdle P.A., Sap flow in trembling aspen, Tree Physiol. 17 (1997) 501-509.

[12] Kramer P.J., Water used in plants, Academic Press, San Diego, CA, 1983, 489 p.

[13] Lambs L., Muller E., Sap flow and water transfer in the Garonne River riparian woodland, France: first results on poplar and willow, Ann. For. Sci. 59 (2002) 203-315.

[14] Lemoine D., Peltier J.P., Marigo G., Comparative studies of the water relations and the hydraulic characteristics in Fraxinus excelsior, Acer pseudoplatanus and A. opalus trees under soil water contrasted conditions, Ann. For. Sci. 58 (2001) 723-731.

[15] Lemoine D., Cochard H., Granier A., Within crown variation in hydraulic architecture in beech (Fagus sylvatica L.): evidence for a stomatal control of xylem embolism, Ann. For. Sci. 59 (2002) 19-27.

[16] Marigo G., Peltier J.P., Analysis of the diurnal change in osmotic potential in leaves of Fraxinus excelsior L., J. Exp. Bot. 47 (1996) 763-769.

[17] Marigo G., Peltier J.P., Girel J., Pautou G., Success in the demographic expansion of Fraxinus excelsior L., Trees 15 (2000) 1-13.

[18] Meiresonne L., Nadezhdina N., Cermak J., Van Slycken J., Ceulemans R., Measured sap flow and simulated transpiration from a poplar stand in Flanders (Belgium), Agr. For. Meteorol. 96 (1999) $165-179$.

[19] Nadezhdina N., Cermak J., Ceulemans R., Radial patterns of sap flow in woody stems of dominant and understory species, Tree Physiol. 22 (2002) 907-918.

[20] Nadezhdina N., Tribtsch H., Cermak J., Infra-red images of heat field around a linear heater and sap flow in stems of lime trees under natural and experimental conditions, Ann. For. Sci. 61 (2004) 203213.

[21] Nagler P.L., Glenn E.P., Thompson T.L., Comparison of transpiration rates among saltcedar, cottonwood and willow trees by sap flow and canopy temperature methods, Agr. For. Metereol. 3110 (2003) $1-14$.

[22] Pautou G., Peiry J.L., Girel J., Blanchard E., Hughes F., Richards K., Harris T., El-Hames A., Space-time units in floodplains: the example of the Drac river upstream of Grenoble, Global Ecol. Biogeogr. Lett. 6 (1997) 311-319.

[23] Peltier J.P., Marigo G., Mécanismes d'ajustement et stress hydrique chez le frêne commun, C.R. Acad. Sci. 319 (1996) 425-429.

[24] Peltier J.P., Marigo G., Drought adaptation in Fraxinus excelsior L.: physiological basis of the elastic adjustment, J. Plant Physiol. 154 (1999) 529-535. 
[25] Richter H.G., Dallwitz M.J., Commercial timbers: descriptions, illustrations, identification, and information retrieval, Version: 18th October 2002, http://biodiversity.uno.edu/delta/.

[26] Rood S.B., Patino S., Coombs K., Tyree M.T., Branch sacrifice: cavitation-associated drought adaptation of riparian cottonwoods, Trees 14 (2000) 248-257.

[27] Rood S.B., Polzin M.L., Big old cottonwoods, Can. J. Bot. 81 (2003) 764-767.

[28] Schaeffer S.M., Williams D.G., Goodrich D.C., Transpiration of cottonwood/willow forest estimated from sap flux, Agr. For. Meteorol. 105 (2000) 257-270.

[29] Schulze E.D., Carbon dioxide and water vapour exchange in response to drought in the atmosphere and in soil, Ann. Rev. Plant Physiol. 37 (1986) 247-274.

[30] Smith S.D., Wellington A.B., Nachlinger J.L., Fox C.A., Functional responses of riparian vegetation to streamflow diversion in the Eastern Sierra Nevada, Ecol. Appl. 1 (1991) 89-97.

[31] Tissier J., Lambs L., Peltier J.-P., Marigo G., Relationships between hydraulic traits and habitat preference for six Acer species occurring in the French Alps, Ann. For. Sci. 61 (2004) 81-86.
[32] Turner N.C., Correction of flow resistances of plants measured from covered and exposed leaves, Plant Physiol. 68 (1981) 1090-1092.

[33] Tyree M.T., Sinclair B., Lu P., Granier A., Whole shoot hydraulic resistance in Quercus species measured with a high-pressure flowmeter, Ann. Sci. For. 50 (1993) 417-423.

[34] Tyree M.T., Kolb K.J., Rood S.B., Patino S., Vulnerability to drought-induced cavitation of riparian cottonwoods in Alberta: possible factor in the decline of the ecosystem? Tree Physiol. 14 (1994) 455-466.

[35] Vertessy R.A., Benyon R.G., O'Sullivan S.K., Gribben P.R., Relationships between stem diameter, sapwood area, leaf area, and transpiration in a young mountain ash forest, Tree Physiol. 15 (1995) 559-567.

[36] Willmer C., Fricker M., Stomata, 2nd ed., Chapman \& Hall, London, Glasgow, New York, Tokyo, Melbourne, Madras, 1996.

[37] Wullschleger S.D., Meinzer F.C., Vertessy R.A., A review of whole plant water use studies in trees, Tree Physiol. 18 (1998) 449-512.

[38] Zimmerman M.H., Xylem Structure and the Ascent of Sap, Springer-Verlag, Berlin, 1983 
